Article

\title{
Consequences of Climate Change Impacts and Incidences of Extreme Weather Events in Relation to Crop Production in Bhutan
}

\author{
Ngawang Chhogyel ${ }^{1,2, *}$, Lalit Kumar ${ }^{1}\left(\mathbb{D}\right.$ and Yadunath Bajgai ${ }^{3}$ (D) \\ 1 School of Environmental and Rural Science, University of New England, Armidale NSW 2351, Australia; \\ lkumar@une.edu.au \\ 2 Agriculture Research and Development Centre, Bajo, Department of Agriculture, Ministry of Agriculture \\ and Forests, Wangdue Phodrang 14001, Bhutan \\ 3 National Potato Program, Agriculture Research and Development Centre, Yusipang, Department of \\ Agriculture, Ministry of Agriculture and Forests, Thimphu 11001, Bhutan; ybajgai@moaf.gov.bt \\ * Correspondence: nchhogye@myune.edu.au or cngawang11@gmail.com
}

Received: 28 February 2020; Accepted: 20 May 2020; Published: 25 May 2020

check for updates

\begin{abstract}
Being a country in the Himalayas, Bhutan is highly prone to the vagaries of weather events that affect agricultural production and the subsequent livelihood of the people. To identify the main issues that affect crop production and the decisions of farmers, a survey was conducted in three different agro-ecosystems in Bhutan. Our key findings indicate that farming and the decisions of farmers were largely affected by different climatic and non-climatic factors. These were in descending order of importance: irrigation availability $>$ farm labour $>$ crop seasonality $>$ crop damage (climatic) $>$ land holding $>$ crop damage (wildlife) $>$ crop damage (diseases and pests). The most important consequences of climate change impacts were the drying of irrigation sources (4.35) and crop losses due to weather events (4.10), whereas land fallowing, the occurrence of flood and soil erosion, weed pressure and changes in cropping pattern (with mean ratings of 2.53-3.03) experienced lesser consequences. The extreme weather events, such as untimely rains, drought and windstorms, were rated as the 'most common' to 'common' occurrences, thus inflicting a crop loss of $1-19 \%$. These confirm our hearsay knowledge that extreme weather events have major consequences on irrigation water, which is said to be either drying or getting smaller in comparison to the past. Therefore, Bhutan must step up its on-ground farmer-support system towards improving the country's food production, whilst embracing climate smart farm technologies for adapting to the impacts of change.
\end{abstract}

Keywords: agro-ecosystem; crop damage; environment; farming; livelihood; sustainability; weather events

\section{Introduction}

The bio-physical factors of the environment and socio-economic conditions of the farmers play an important role in agricultural crop production and farming business enterprises [1]. While technological advances have fueled growth in agriculture, farming has become increasingly challenging in recent years, mainly due to the impacts of climate change $[2,3]$. Among the climate change-induced incidences, the occurrence of extreme weather events has become a more common phenomenon, and these are projected to be more frequent into the future $[4,5]$. Such incidences have reportedly influenced crop production and the management decisions of many farmers across the globe $[1,6-8]$. The extreme weather events were also considered to be impacting the developmental pace and progress of many developing countries across the world [9]. Estimations showed that economic losses from weather and 
climate-related disasters cost over USD 200 billion, annually [10]. With climate change proving to have real impacts, both in terms of frequency and severity, extreme weather events and their associated impacts are likely to increase manifold in the future.

According to the Intergovernmental Panel on Climate Change (IPCC), "An extreme (weather or climate) is generally defined as the occurrence of a value of a weather or climate variable above (or below) a threshold value near the upper (or lower) ends (tails') of the range of observed values of the variable" [10]. While studies have reported many forms of extreme weather events, the most common ones include heat waves, windstorms and cyclones, floods, droughts, rising sea level, and high-intensity precipitation [11,12]. These events have been attributed to the changes in the climatic conditions and are sensitive to the natural and human systems [12,13]. It has been reported that agriculture, transportation, infrastructure, water, tourism and coastal settlements in both developed and developing countries fall under increasing risk of climate extremes. Studies have revealed that the mighty Himalayas and Hindu Kush regions are climatically very sensitive and have been experiencing large impacts of climate change in recent years [14,15]. Moreover, Bhutan is located in the eastern part of the Himalayas $[14,16]$, where the impacts of global warming are reported to be very severe $[17,18]$. In the last couple of decades, the country has been witnessing a number of extreme weather events, such as hailstorms, windstorms, cyclones, droughts, and localized high-intensity and erratic rains $[19,20]$. Dorji and Tamang [21], analysed the historical climate of Bhutan and reported large variability in climatic conditions and associated hazards, such as heavy seasonal rains, flooding and landslides. Ren et al. [22] also reported that the annual precipitation trend in the entire Hindu Kush region showed large increases in the last couple of decades, although there were spatial variations in different countries, however, it should be mentioned that this was a broad-scale study using coarse-resolution data. Furthermore, there was a report on the increasing rate of snows and glacial melts in the northern parts of the country, thus posing a risk of Glacial Lake Outburst Flood (GLOF) [23]. The country has already experienced a few devastating incidences of GLOF in recent years, among which the GLOF of 1994 was the most severe [24,25]. It caused extensive damage to agricultural land, housing, livestock, infrastructure and communication networks. With an unabated upward trend in temperature due to the warming of the earth, glaciers in Bhutan are said to be retreating very quickly $[17,26]$. This is likely to trigger major GLOF since the country is confirmed to have 24 potentially dangerous glacial lakes situated between 4000-6000 m above mean sea level [25]. Climate change impacts, such as these, and many incidences of extreme weather events, especially high-intensity rainfall events, will enhance the erosive activities of rivers and streams, thus contributing to increasing levels of soil loss [27]. Therefore, the combined effects of weather phenomena, together with land degradation factors, would negatively impact environment conservation and agricultural development in the country. It is known that the extreme weather events are becoming quite frequent, and more severe. According to Sheikh et al. [28], temperature and precipitation extremes have increased over southern Asia, particularly in the eastern Himalayas. Similarly, the effects of climate change pose a serious challenge to agricultural production in Bhutan [19,29]. Elsewhere, between 2012 and 2014, there were incidences of extreme heatwaves in California, winter storms in North America, high-intensity winter rain in the United Kingdom, record rainfall and flooding in Indonesia and a severe heat wave in Australia [30]. There were also reports of heatwaves, dangerous bushfires and a series of destructive tropical cyclones causing colossal loss and damage to properties and infrastructure in Australia [5]. All these indicate issues of extreme weather events, which are attributed to the changes in climate system caused by global warming. Moreover, developing countries and island states are most vulnerable to the impacts of climate change [31-33].

Drawing experience from other countries, and based on local observations, it is critical for Bhutan to collate and analyse all information linked to the ill-effects of weather extremes for scenario-building and possible extrapolations towards sustainable farming systems. This is expected to offer well substantiated information not only for managing limited resources effectively, but also to facilitate the identification of suitable climate change adaptation strategies [34-36]. The current research was aimed 
at providing information on a range of issues that contribute to sustainable agricultural production. Thus, the objectives of the study were: (1) the identification and ranking of the main issues (as factors) impeding farm works, or the decisions of farmers, and (2) to reduce knowledge gaps concerning the consequences of climate change impacts, including the impacts of extreme weather events on individual farmers' experiences. These data are required not only for agriculture, but also for overall risk management, development and planning. Besides, there is an urgent need to improve the country's database on disasters related to extreme weather for long-term adaptation efforts and climatic resilience, which, in the current context, is at a nascent stage.

\section{Materials and Methods}

This study was carried out from March-May in 2019, spanning over six districts of Bhutan (Paro, Wangduephodrang, Punakha, Tsirang, Sarpang and Samtse). Ecologically, these six study districts represent the high, mid and low agro-ecosystems of the country and are located between $26^{\circ} 42^{\prime} 2.36^{\prime \prime} \mathrm{N}$ to $28^{\circ} 14^{\prime} 51.64^{\prime \prime} \mathrm{N}$ latitudes, and $89^{\circ} 46^{\prime} 5.7^{\prime \prime} \mathrm{E}$ to $90^{\circ} 32^{\prime} 3.29^{\prime \prime} \mathrm{E}$ longitudes [37]. The elevation of the study site ranges between 100 and $2600 \mathrm{~m}$ above mean sea level and is bordered by China in the north and India in the south, east and west. As indicated in the study site map (Figure 1), Samtse and Sarpang districts fall in the southern subtropical zone $(<1000 \mathrm{~m})$, whereas Tsirang, Punakha and major parts of Wangduephodrang (Wangdue) are in the mid-altitude zone (elevation between 1000-2000 m). Paro and northern parts of Wangdue and Punakha are typically in the high-altitude zone, with elevations of more than $2000 \mathrm{~m}$ above mean sea level. Thus, these districts could very well represent the varying environmental conditions of Bhutan and their challenges related to the issues with climate change and socio-economic factors. The physiography of Bhutan is such that there are dramatic changes in elevation over even very small distances $[16,38]$. This has given rise to large variations in climatic conditions that affect farming and livelihood of the people.

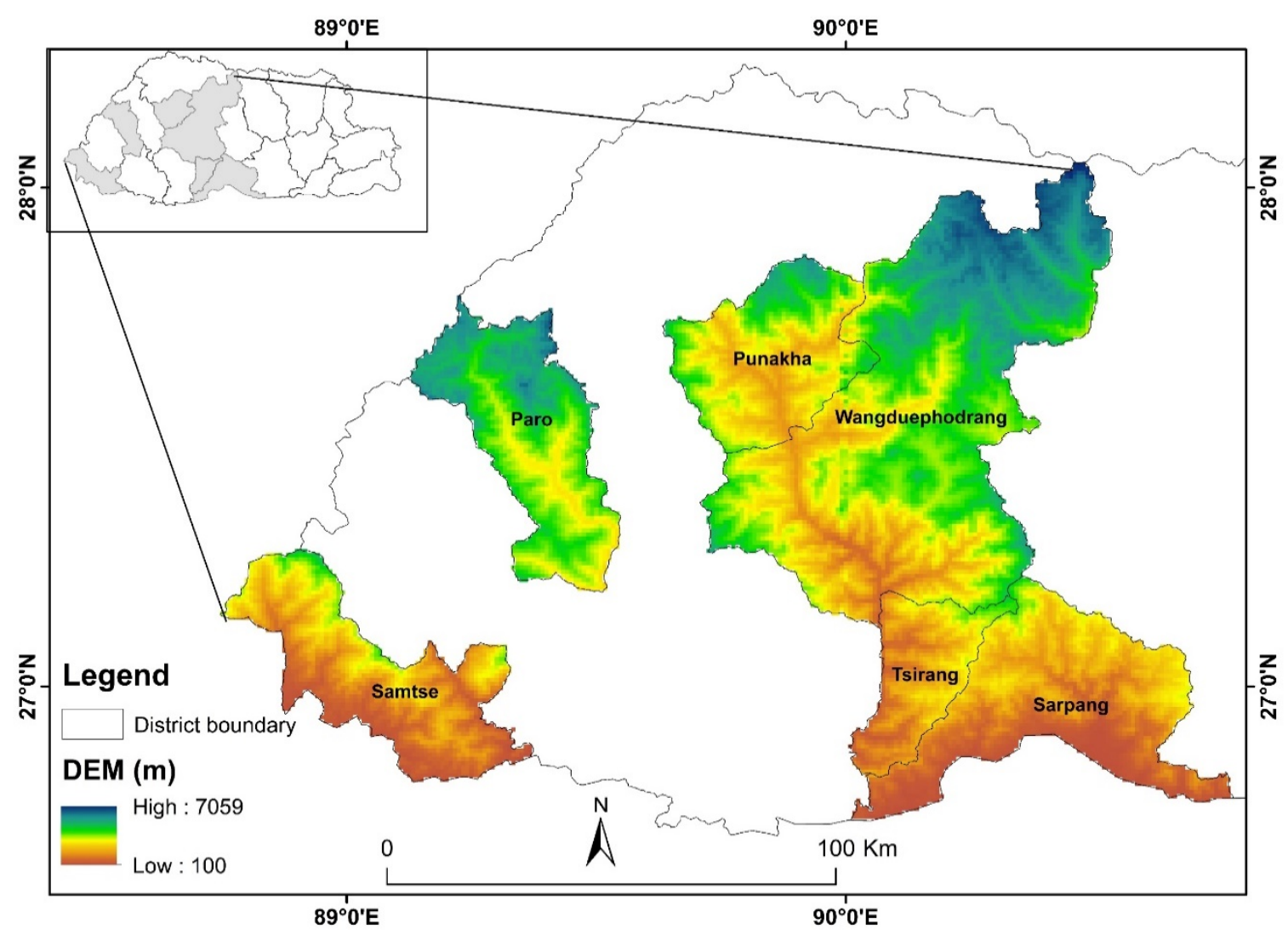

Figure 1. Map of Bhutan indicating study site (six districts). 
The survey was undertaken using a semi-structured questionnaire, which is considered as a versatile technique that offers focused structure for discussion $[39,40]$. The questionnaire survey was designed in such a way so that the interview did not take more than $45 \mathrm{~min}$ per farmer. During the survey, 40 random samples of farmers were taken from each of the districts, resulting in a total of 240 samples from six districts, comprising of 117 males and 123 females. This means that the study had more than the minimum number households $(>30)$ required for statistical validity and thus representation. Six different districts were selected from three different agro-ecological climatic zones, and this is representative of the Bhutan environment. The actual survey was carried out by the extension officers of the six respective districts, given their experiences and knowledge about farmers and the study sites [41]. To achieve uniformity of data across the regions, the extension officers were trained prior to actual execution of the survey. The questions in the questionnaire were framed based on our hypothesis that the "climatic factors could be one of the most important issues affecting farming and the farm-decision making in Bhutan". While the survey assessed a wide range of issues affecting Bhutanese farmers, a major focus was on to identify the relative position of climatic factors, among the issues affecting the farming system in Bhutan. In order to relate these issues, detailed information on the frequency and severity of extreme weather events, including accounts of the consequences of climate change impacts either observed or experienced by the focal farmers. Six different types of extreme weather events considered in this study were drought, untimely rain, heat waves, high-intensity/heavy rain, warmer winters and windstorms.

To gather information on important issues affecting farming, the farmers were asked to share their experiences on some of the common climatic and non-climatic issues either observed, or felt by the individual farmer, or their household. Following the Likert scale technique, we used point scales to score the responses of the farmers [42,43]. The responses were rated on a point scale of 1 to 5 where: $5=$ most common, $4=$ very common, $3=$ common, $2=$ somewhat common and $1=$ least common. Similarly, a point scale of 1 to 5 was used to assess ratings for the consequences of climate change impacts experienced by the farmers, including the frequency and severity of extreme weather events. However, in the case of frequency of extreme weather events, farmers were asked to comment on the frequency, or prevalence, of the different forms of extreme weather events, which were also rated on a 1 - to 5 -point scale $(5=$ most common, $4=$ common, $3=$ somewhat common, $2=$ less common, and $1=$ least common). Likewise, for severity, farmer's views were sought on the extent of crop damages caused by the different weather events, also utilizing a 1 - to 5 -point scale $(5=$ most severe, $4=$ severe, $3=$ somewhat severe, $2=$ less severe and $1=$ least severe). The responses of the farmers (rating points) were analysed to rank them in descending order of the relative positions occupied by the issues. For this, a weighted average, with weights of 1 to 5 , were assigned corresponding to the ranking scale of 1 to 5 and then calculated using a simple arithmetic formula (Equation (1)). To provide holistic information on the impacts of extreme weather events, the last question was on the extent of actual crop damage in terms of percentages. The scales for the crop damage, or crop loss were rated against the eight most commonly grown crops on the scale of: (1) $<10 \%$, (2) $11-19 \%$, (3) $20-29 \%$, (4) $30-39 \%$, and (5) $>40 \%$ for the $1-5$ rating points, respectively.

$$
\mathrm{X}=\frac{\sum_{i=1}^{n} w_{i} \mathrm{x}_{\mathrm{i}}}{\sum_{i=1}^{n} w_{i}}
$$

where $X$ is the weighted average mean, $x_{i}$ is the multiset of data, and $w_{i}$ is the weights (1-5) assigned to each of the data sets.

As part of this study, we obtained some relevant information on the age, family size, land holding, farm work experience and number of crops grown by the farmers (Table 1). The data in the table shows that the mean age of the participating farmers was 50 years, with a mean family size of 5 . It also indicates that the farmers interviewed had a mean farming work experience of 30 years, thus indicating that the data were of the actual farmers who have been experiencing various forms of issues and hardships in the villages. 
Table 1. Information on the farmer respondents interviewed.

\begin{tabular}{ccccc}
\hline Particulars & Mean & Standard Deviation & Minimum & Maximum \\
\hline Age (years) & 50.00 & 11.88 & 22.00 & 76.00 \\
Family size (number) & 5.00 & 1.40 & 2.00 & 9.00 \\
land holding (ha) & 1.40 & 2.01 & 0.16 & 5.80 \\
Farming experience (years) & 30.00 & 13.00 & 5.00 & 65.00 \\
Crops grown (number) & 5.00 & 1.64 & 1.00 & 9.00 \\
\hline
\end{tabular}

The information gathered from the survey was pre-processed in Microsoft Excel and data analysis was undertaken using statistical software R, version 3.5.1 [44]. Among the R packages, we used 'Dplyr', 'tidyverse' and 'ggplot2' for plotting works. Comparison of means were subjected to an analysis of variance (ANOVA) and descriptive statistics were also applied to obtain means, standard deviations, data range, minimum and maximum values of the variables used in the study. While all graphs and plotting computations were undertaken in R, ArcGIS version 10.5 was used for visualization. The Shapefile of Bhutan map (country boundary with administrative sub-division) and digital elevation model (DEM) was obtained from the Ministry of Agriculture and Forest, Royal Government of Bhutan.

The meteorological data (1996-2017) used in the current study was obtained from the National Centre for Hydrology and Meteorology (NCHM), Ministry of Economic Affairs, Royal Government of Bhutan. The general information of rainfall and temperature at the study sites showed decreasing and increasing trends, respectively, although temperature increases were not clearly visible during the same study period (Figure 2). It should be noted that the rainfall and temperature data are only for a 20 -year period, and longer period data would be needed to confirm any trends. These data are not available for Bhutan.

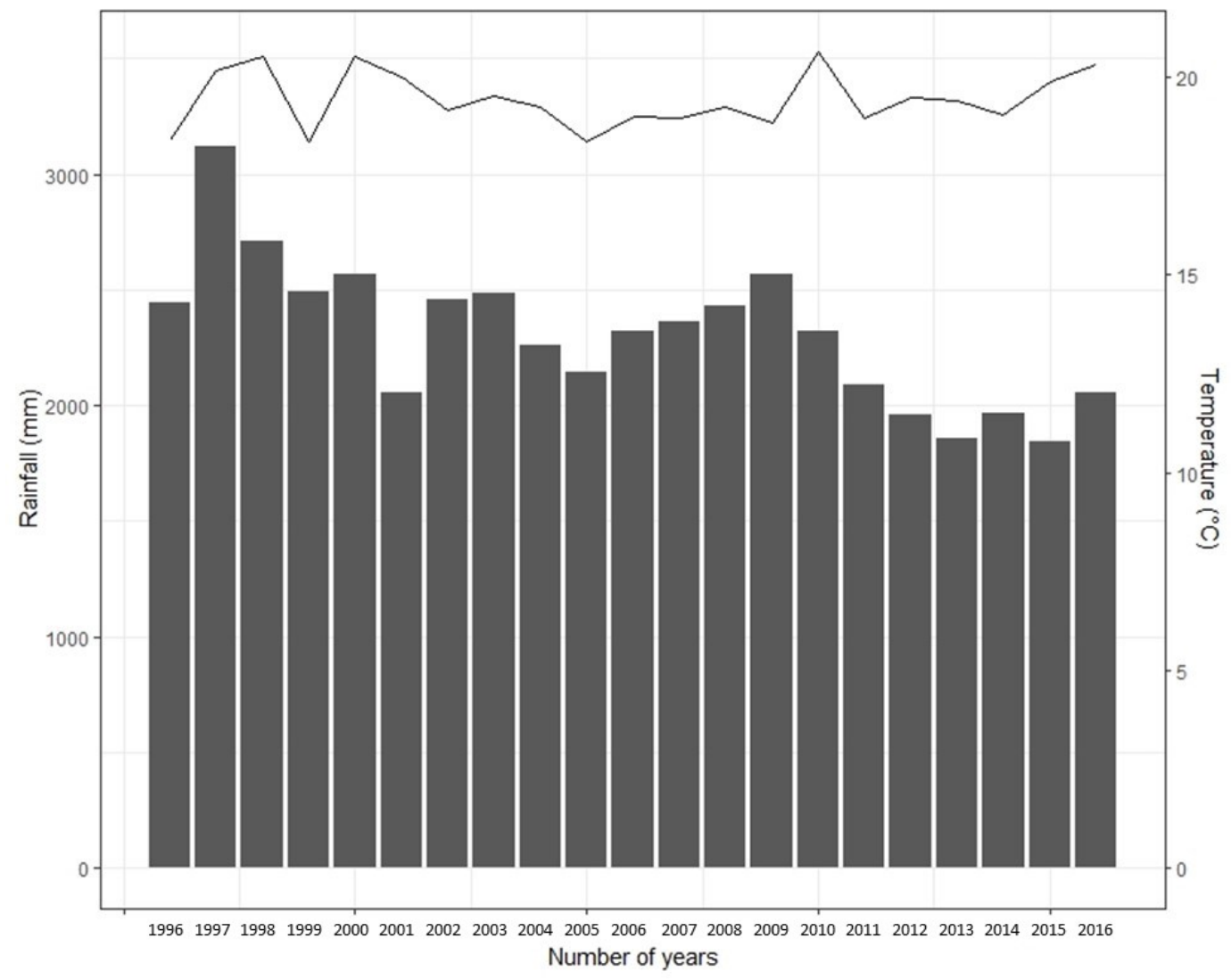

Figure 2. Rainfall and temperature trend of study sites for the last 20 years (1996-2017) (Rainfall is shown by the bars and temperature by line graph). 


\section{Results}

\subsection{Issues in Farming}

The analysis showed that issues experienced by the farmers differed among the study districts (Figure 3). Farmers were affected with a number of issues, or factors that affected agricultural farming. These factors contributed to variability in farmers' decision to adapt or undertake farming technologies $[36,45,46]$. Specifically, farm labour shortage and availability of irrigation water played important roles in farming operations as the two topmost important issues. These two were closely followed by crop seasonality and crop damage due to weather events. A majority of the responses of the farmer rated these factors as 'most important' and 'important', thus indicating the importance of these factors in farmers' decision-making process (Table 2). Other factors, such as crop damage by wildlife (animals), and land holdings, also contributed to the farmers' decision on farming. Furthermore, the weighted average ranking of these factors showed that the availability of irrigation water and farm labour shortage were the top two most important factors influencing the farmers' decisions (Table 2). The weighted average score-based issues in descending order of importance were: irrigation availability $>$ farm labour $>$ crop seasonality $>$ crop damage (climatic) $>$ land holding $>$ crop damage (wildlife) $>$ crop damage (diseases and pests).

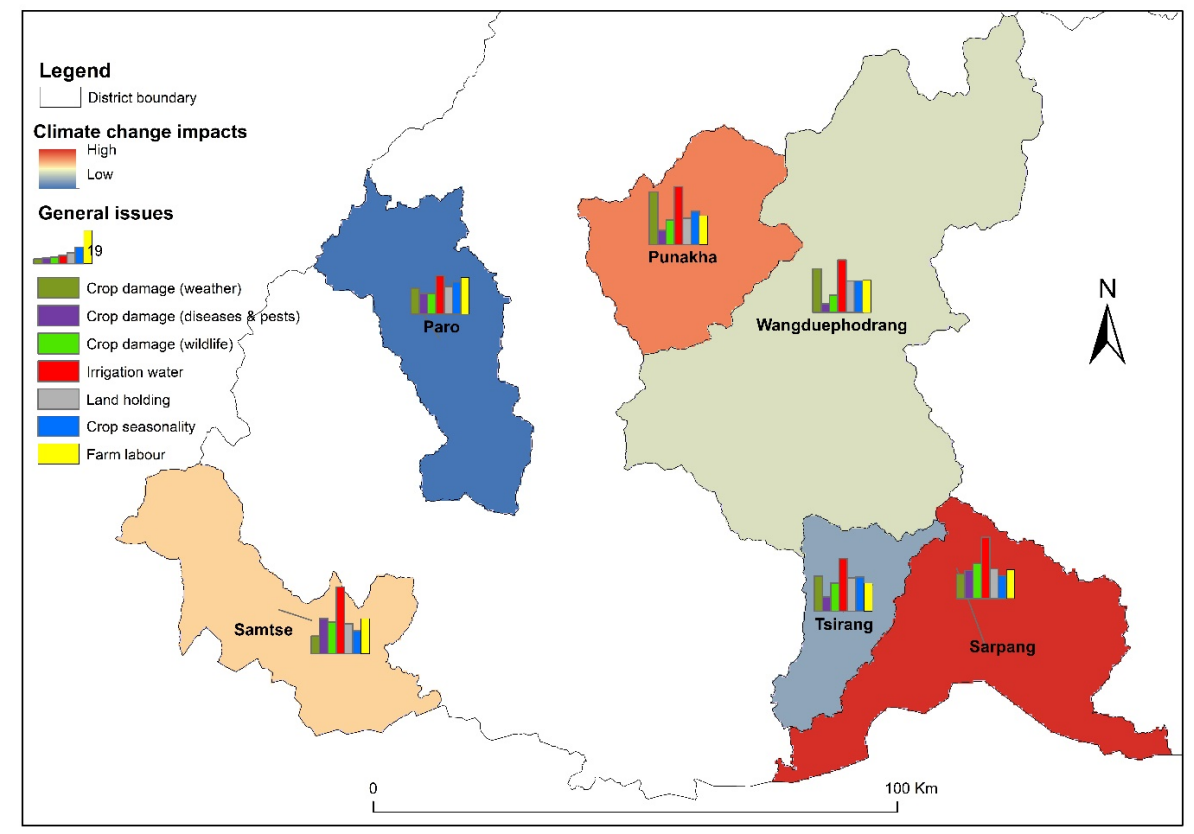

Figure 3. Issues affecting the decisions of farmers and variations in climate change impacts in the study districts.

Table 2. Ranking of the issues influencing agricultural crop production based on number of respondents (percent respondents).

\begin{tabular}{ccccccc}
\hline \multirow{2}{*}{ Factors } & \multicolumn{5}{c}{ Ranking Scale } & \multirow{2}{*}{ Weighted Average } \\
\cline { 2 - 6 } & $\mathbf{1}$ & $\mathbf{2}$ & $\mathbf{3}$ & $\mathbf{4}$ & $\mathbf{5}$ & \\
\hline Irrigation availability & 6 & 10 & 17 & 35 & 32 & 25.13 \\
Farm labour & 9 & 11 & 23 & 25 & 32 & 24.00 \\
Crop seasonality & 8 & 16 & 32 & 28 & 16 & 21.87 \\
Crop damage (climatic) & 10 & 23 & 26 & 29 & 12 & 20.67 \\
Land holding & 20 & 34 & 20 & 16 & 10 & 17.47 \\
Crop damage (wildlife) & 21 & 35 & 27 & 13 & 4 & 16.27 \\
Crop damage (dis and pests) & 27 & 36.2 & 25 & 27 & 2 & 14.69 \\
\hline
\end{tabular}

Rating: $5=$ most important, $4=$ important, $3=$ somewhat important, $2=$ less important and $1=$ least important. 


\subsection{Experiences of Extreme Weather Events}

Extreme weather events were assessed to be highly significant in terms of the frequency and severity at an alpha threshold of $p<0.001$ (Table 3). Among six districts, the two southern districts of Sarpang and Samtse experienced the most frequent forms of extreme weather events with scores of 22.40 and 22.40, respectively. These two districts were followed by Punakha (score of 19.97) and Wangdue (19.65), and Tsirang had a mean score of 18.62. The least impacted district was Paro with a mean score of 16.40, thus indicating that this district had not experienced frequent extreme weather events as compared to other districts. In the case of severity, Samtse farmers (score of 19.80) had experienced more severe forms of extreme weather events in comparison to other study districts, followed by Sarpang with a mean score of 18.47. In terms of the total impacts of climate change, Sarpang was assessed as the most affected district, followed by Punakha and Samtse (Figure 3). Generally, the two southern districts of Sarpang and Samtse were found to be the most impacted, but other districts were also assessed to have experienced both frequent and severe forms of extreme weather events. However, Paro scored the lowest impacts, thus indicating that farmers in the district were not much affected as compared to other districts.

Table 3. Comparison of the mean score of frequency and severity in the study districts.

\begin{tabular}{ccc}
\hline Districts & Frequency $^{* * *}$ & Severity $^{* * *}$ \\
\hline Paro & 16.40 & 17.70 \\
Punakha & 19.97 & 16.65 \\
Samtse & 22.40 & 19.80 \\
Sarpang & 22.42 & 18.47 \\
Tsirang & 18.62 & 17.57 \\
Wangdue & 19.65 & 16.47 \\
\hline$p$ value & $2.00 \times 10^{-16}$ & $2.40 \times 10^{-8}$
\end{tabular}

Among the extreme weather events, $57 \%$ and $45 \%$ of the respondents had categorized untimely rain and drought as the 'most common' weather events, respectively. Likewise, 37\% and 32\% of the respondents felt that the drought and untimely rains were not that frequent and were categorized as 'common' phenomena (Figure 4). However, $13 \%, 9 \%$ and $35 \%$ of the respondents rated drought, untimely rains and windstorms, respectively, as 'somewhat' occurring weather events. Windstorms were also analysed to be making occasional landfalls with $30 \%$ of the farmers reporting it as 'common'. Heat waves and warmer winters were the two least frequent events, with only $1-3 \%$ of the farmers reporting these as 'most common' events. Though there is a dearth of information on such issues, the current study indicated that incidences of heat waves and warmer winters are at least present in Bhutan. Heat waves and warmer winters were considered as one of the most important issues of climate change in the neighbouring northern states of India [47]. Moreover, regardless of their frequency, some of these extreme weather events have been reportedly impacting farmers in the neighbouring Nepal [48,49], which share a similar climatic environment to Bhutan. In terms of the severity of individual extreme weather events, untimely rains (54\%) and droughts (34\%) were also the most severe forms of extreme weather events experienced by the farmers surveyed in this study (Figure 5). Similarly, 26\% of the respondents had rated windstorm as 'severe' in terms of its impact. 


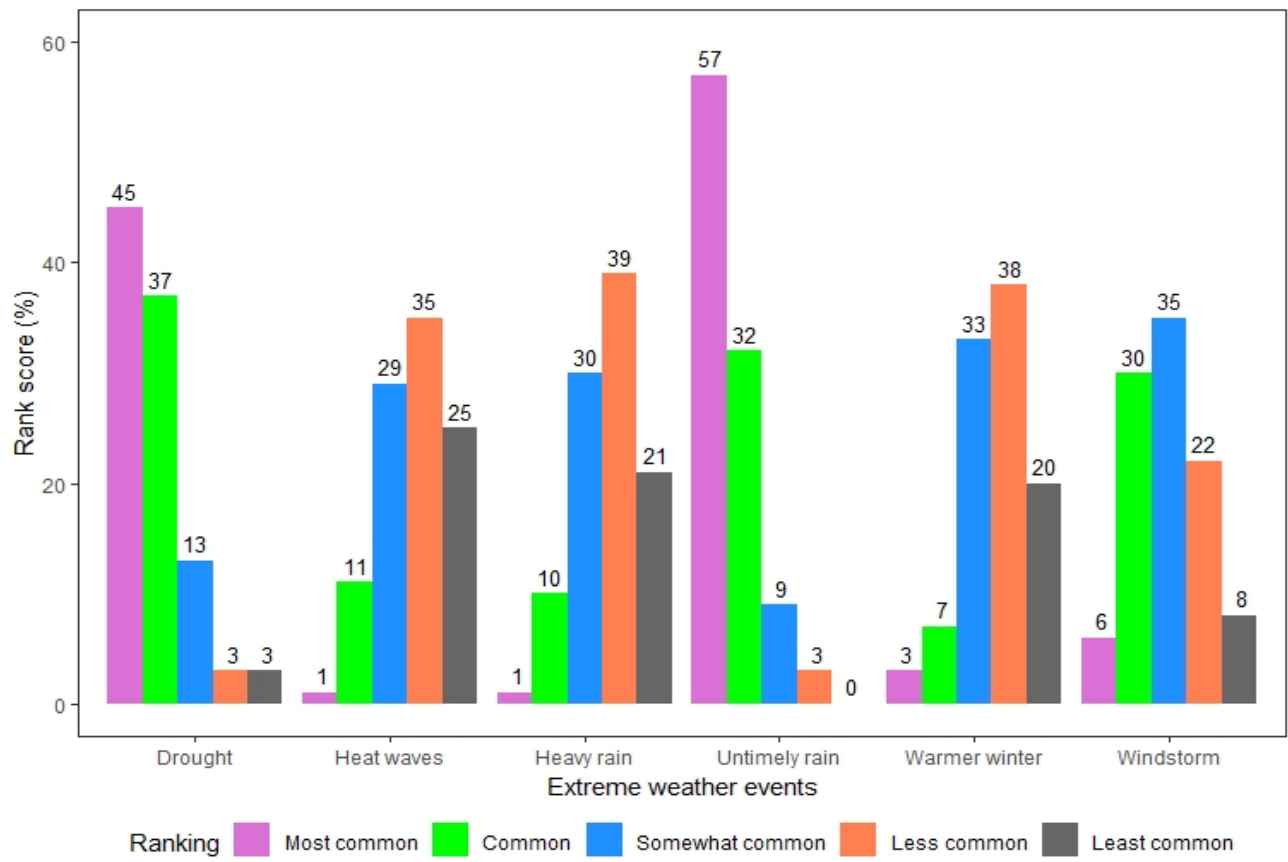

Figure 4. Frequency ranking analysis of extreme weather events.

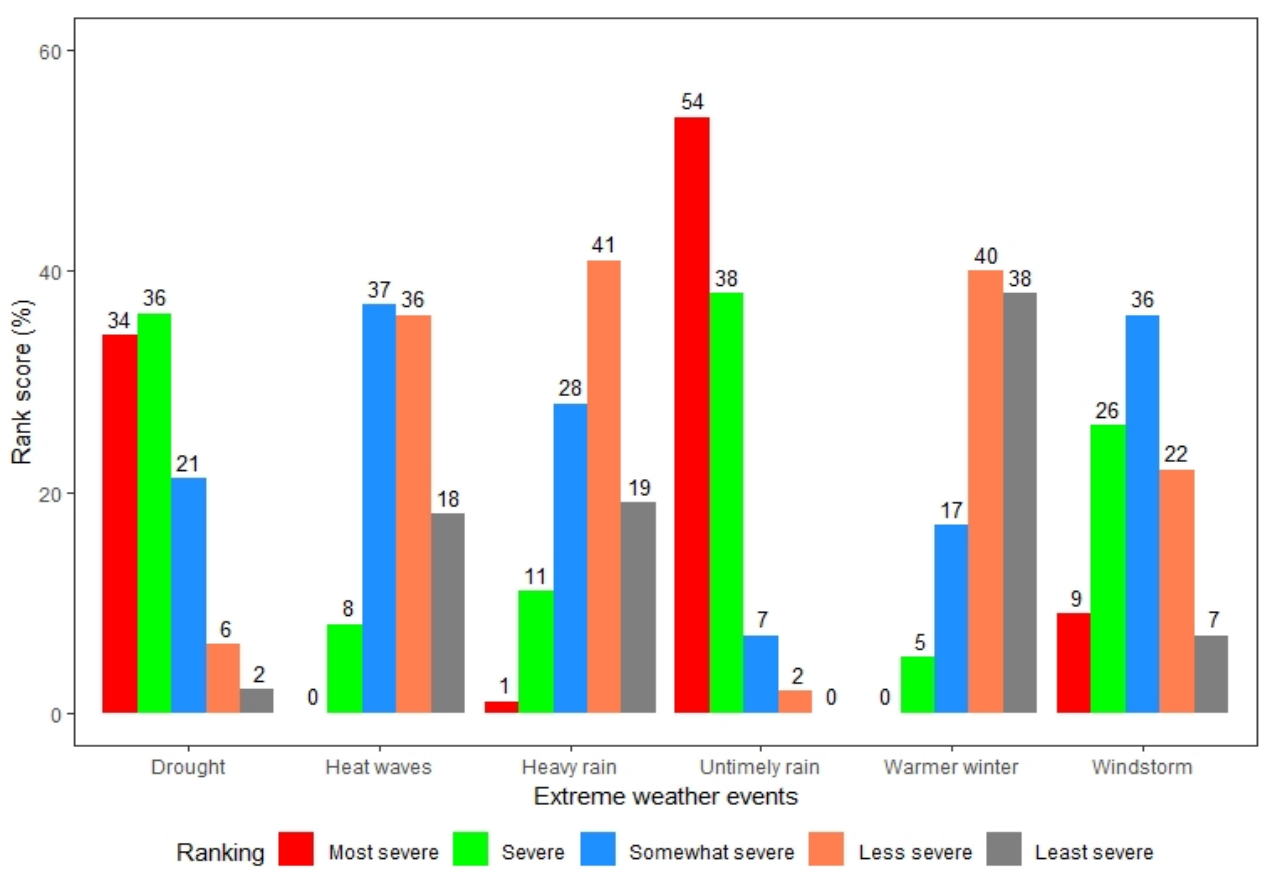

Figure 5. Severity ranking analysis of extreme weather events.

\subsection{Consequences of Climate Change Impacts}

Our findings show that the various consequences of climate change impacts differed significantly across the districts (Table 4). The farmers in the five districts of Punakha, Samtse, Sarpang, Tsirang and Wangdue felt that the irrigation sources were affected the most with a mean score of 4.35 on a scale of 1-5. This was closely followed by crop losses due to the extreme weather events (mean score of 4.10). Studies in neighbouring India have also reported similar consequences of climate change impacts [50]. In the high-altitude district of Paro, changes in cropping pattern were the topmost important consequence of climate change impact, followed by incidences of diseases and pests. Furthermore, flood and erosion, weed pressure, cropping pattern change and land fallowing were the 
other consequences of the impacts of climate change that were categorized as 'somewhat common' to 'less common', with their mean scores ranging between 2.75-3.25. These consequences, if not addressed in a timely manner, could turn out to be a potential disaster in the near future under the unmitigated ongoing impacts of global warming.

In terms of its impacts on crop production, the majority of the farmers rated crop damage of 1-19\% (Table 5. Rice, maize and potato damages of 11-19\% were reported by higher percentage of surveyed farmers. Crops, such as vegetables, and fruits and nuts had a higher percent of people reporting less than $10 \%$ crop loss. The correlation of crop damage to both frequency and severity analysis showed a positive trend (Figure 6a,b), indicating an increased challenge for the farmers.

Table 4. Different consequences of climate change impacts experienced by farmers in six study districts based on a rating scale of $1-5$.

\begin{tabular}{|c|c|c|c|c|c|c|c|}
\hline Districts & $\begin{array}{c}\text { Crop Loss } \\
\text { (Weather) }\end{array}$ & $\begin{array}{l}\text { Irrigation } \\
\text { Sources } * * *\end{array}$ & $\begin{array}{c}\text { Diseases \& } \\
\text { Pests } * * *\end{array}$ & $\begin{array}{c}\text { Weed } \\
\text { Pressure }\end{array}$ & $\begin{array}{l}\text { Cropping } \\
\text { Pattern ns }\end{array}$ & $\begin{array}{c}\text { Flood \& } \\
\text { Erosion } * * *\end{array}$ & $\begin{array}{c}\text { Land } \\
\text { Fallowing * }\end{array}$ \\
\hline Paro & 2.97 & 3.07 & 3.10 & 2.48 & 3.25 & 1.90 & 2.25 \\
\hline Samtse & 4.22 & 4.52 & 3.32 & 3.20 & 3.20 & 3.17 & 3.02 \\
\hline Sarpang & 4.72 & 4.62 & 3.50 & 3.25 & 3.07 & 3.15 & 2.75 \\
\hline Tsirang & 4.40 & 4.75 & 2.65 & 2.48 & 2.65 & 1.95 & 2.57 \\
\hline$p$ value & $2 \times 10^{-16}$ & $2 \times 10^{-16}$ & $15 \times 10^{-6}$ & $5.1 \times 10^{-9}$ & 0.07 & $9.79 \times 10^{-12}$ & 0.017 \\
\hline
\end{tabular}

Table 5. Extent of crop damage based on the percentage of respondents.

\begin{tabular}{ccccccc}
\hline \multirow{2}{*}{ Crops } & \multicolumn{7}{c}{ Estimated Extent of Crop Damage (\%) } & \multirow{2}{*}{ Total (\%) } \\
\cline { 2 - 6 } & $\mathbf{< 1 0}$ & $\mathbf{1 1 - 1 9}$ & $\mathbf{2 0 - 2 9}$ & $\mathbf{3 0 - 3 9}$ & $\mathbf{4 0 0}$ & \\
\hline Rice & 55 & 17 & 3 & 0 & 1 & 76 \\
Maize & 21 & 21 & 5 & 1 & 1 & 49 \\
Minor cereals & 22 & 5 & 1 & 1 & 0 & 29 \\
Potato & 29 & 15 & 4 & 1 & 0 & 49 \\
Vegetables & 73 & 13 & 2 & 1 & 0 & 89 \\
Apple & 6 & 2.00 & 1 & 1 & 1 & 11 \\
Mandarin & 12 & 9.00 & 5 & 0 & 0 & 26 \\
Fruits and nuts & 43 & 6 & 0 & 0 & 0 & 49 \\
\hline Mean & 32.62 & 11.00 & 2.62 & 0.62 & 0.37 & \\
\hline
\end{tabular}
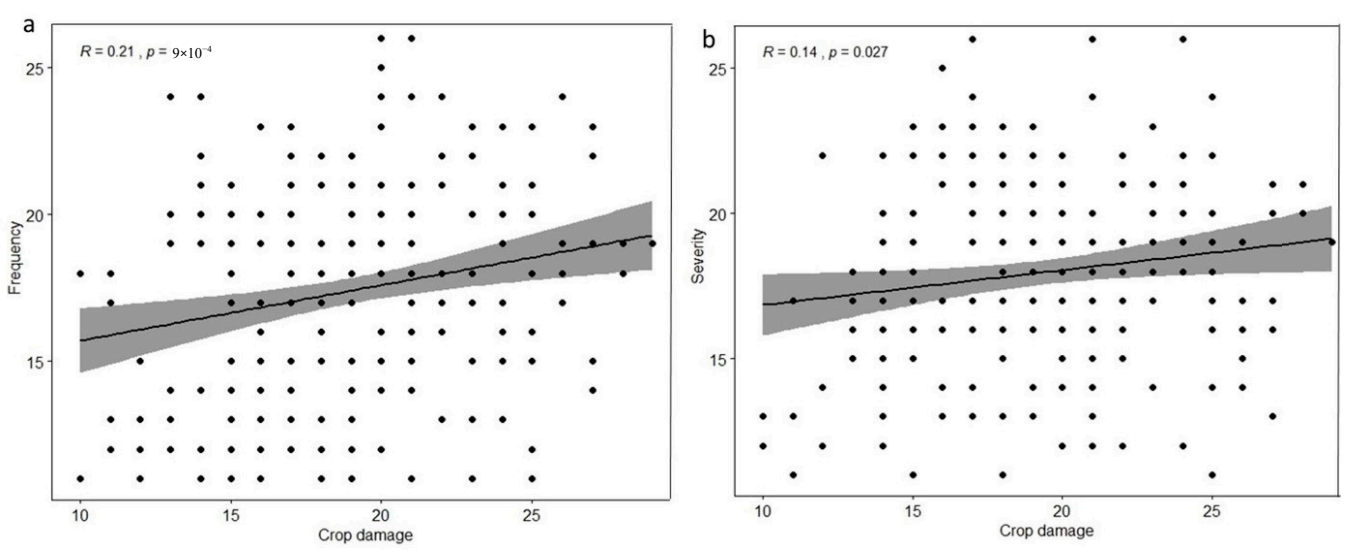

Figure 6. Correlation of total crop damage with the frequency (a) and severity (b) of extreme weather events. 


\section{Discussion}

There can be large differences in the issues faced by farmers across different agro-ecologies due to the variations in environmental and socio-economic conditions. This was exhibited by significantly differing views and experiences shared by the farmers in the study area on the issues affecting their farm work. Studies have reported that farmers' views and perceptions are integral to the adoption of farming technologies and their decision to undertake adaptation strategies [36,51]. In the current analysis, issues of farm labour, irrigation water, crop seasonality and crop damage due to climatic factors were the top four hindrances contributing to the decision-making on their farming practices. While the exposure of farmers to risks and uncertainties are quite common [52], the most pertinent issues identified herein qualify as top priorities for amelioration, especially in an agriculture-driven country such as Bhutan [53]. The weighted average ranking of the issues (Table 2) is a crucial finding as it provides information on areas of focus, requiring technical and policy interventions. It also indicates the relative position of climatic factors, as to where they stand among the issues affecting the farmers. Furthermore, a higher proportion of farmers citing farm labour and irrigation water as the most important issues also indicated that these factors are very important if food and nutritional security are the development targets of the government of Bhutan. The Department of Agriculture in Bhutan has also noticed that farm labour shortage and inadequate irrigation water were frequently reported field issues in the country [54,55]. Similar findings have been reported in Nepal, wherein some of the field issues prevailing in their farming communities of hilly areas were drying of irrigation sources, labour shortages, land fragmentation and large annual crop yield reduction [56,57]. Since Bhutan shares similar environmental conditions and meteorological influences to Nepal, including those of other neighbouring countries in Asia, our study could add much needed empirical evidences as a case study from the region. While farm labour shortages or labour scarcity due to increased rural-urban migration could be country specific, such as in the case of China [58], issues with irrigation water have been reported as one of the most pressing transboundary challenges facing agriculture in many countries of the world due to climate change and socio-economic factors [59-61].

Crop seasonality and climatic factors were among the top four issues experienced by the farmers, which is likely to pose even greater challenges under the predicted increasing impacts of climate change. Researchers in China have reported that crop seasonality and changes in climatic factors have already affected agricultural production [62]. Other issues, such as crop depredation by wild animals, crop damage due to diseases and pests and low landholding indicate that Bhutanese farmers face multiple threats to their practice, indicating that systemic approaches and sustainable solutions are required for ongoing farm sustainability and development. It has been shown that different geographic locations and ecosystems exhibit diverse environmental conditions [63,64]; thus, it is important to gather information on various consequences of climate change impacts observed, or experienced, by the farmers for ecosystem resilience and enhanced farm productivity. It is also equally important to relate these consequences with the issues, thereby helping us delve down to the root causes of farming constraints. This is very relevant for Bhutan, since $49.1 \%$ of its rural population depends on farming for employment and livelihood [65]. Therefore, for improving food self-sufficiency, food security and poverty alleviation, the focus of Bhutan's development must be geared towards overhauling the productivity of the renewable natural resources (RNR) sectors [19]. Though Bhutan has seen an increasing trend in food production over the last decade, mainly due to the adoption of improved technologies, the country is very much concerned with the impacts of climate change that are increasingly being felt in the recent years $[19,66]$. It has been reported that the contribution of RNR sectors (comprising agriculture, livestock and forestry) to the national gross domestic product (GDP) stood at 17.37\% [67]. This shows that the RNR sector's contribution to the GDP is noteworthy and has tremendous potential to bolster socio-economic development of the country. There is a need to enhance investment in agriculture and allied sectors through enhanced rural livelihood support programs and public-private partnership initiatives [68-70]. With different geographic locations and ecosystems experiencing various forms of climate change impacts, identifying the key issues is a 
crucial part in helping farmers cope with their experienced adversities. Our findings show that the magnitude of the issues of climate change impacts differed significantly among the different study districts herein that represent different agro-ecological conditions. A similar study has also reported that farmers across agro-ecological zones have experienced different forms of climate change impacts, such as unpredictable weather, erratic precipitation and drying of water sources [29]. This consolidates the existing understanding that farmers face location-specific problems, ranging from climatic to social issues. Moreover, the 20-year meteorological data of the study sites show a decreasing annual total rainfall, with a slightly increasing temperature, thus supporting the findings of this study (Figure 2). These rainfall and temperature trends provide a link to the issues experienced by the farmers in the study sites. Studies also revealed that mountain springs and streams, which form the main irrigation water sources in the Hindu Kush and Himalayan regions, were observed to be drying or shrinking, thus making farmers highly vulnerable to the impacts of climate change [14,17]. The shrinking of irrigation water sources have been noticed in the mountainous regions of India as well [71]. These issues link well with the report of large anomalies of weather patterns observed within many south Asian countries [28,60], including those in the Asia-Pacific regions [9].

Another very important consequence of climate change impact was crop loss resulting from the incidences of extreme weather events. Extreme weather events have been widely blamed for inflicting heavy crop damages in different parts of the world [6,72]. If left unattended, rural livelihood and food security is likely to be at risk, considering that Bhutan's agricultural system is highly prone to the vagaries of climate change and external shocks [38]. Therefore, the Department of Agriculture and relevant stakeholders in Bhutan must vigorously pursue the climate smart agricultural technologies [66], not only to mitigate climate change impacts but also to overcome the issues for enhanced farm resilience into the future. In this context, information about field issues and climate-related consequences at various socio-economic and environmental conditions is crucial [36]. Understanding the key issues and drivers of changes in different locations needs strategic focus [73]. For instance, the most important consequence of climate change in Paro was cropping pattern changes, whereas, in other areas, irrigation and crop damages due to diseases and pests, and wildlife were more pronounced. Findings such as these also indicate that there is a need to seriously review Bhutan government's environmental policy, which emphasizes on conservation of environment and protection of wildlife [74-76]. While such a stringent environment policy is important, its negative impacts, especially on large crop losses to wildlife would require top attention given the repercussion of land fallowing and rural-urban migration. While this paper did not assess the implications of environment conservation and wildlife protection policies, it is possible that this noble policy might be negatively impacting the farmers. There were reports of human-wildlife conflicts in Bhutan that not only resulted in a large loss of crop and livestock, but also led to the abandoning of precious agriculturally important land $[77,78]$. Cultivable land in Bhutan is considered very precious and the land act of Bhutan provides policy support to protect and safeguard land for the current and future generation [79], but increased land fallowing and the out migration of people indicate a need for further research and more practical policy interventions at the earliest. The current study also shows that land fallowing and soil loss due to flood and erosion were rated as 'common' to 'somewhat common' observations. This information provides an insight into the ecosystem level issues that link well with the generalized patterns of climate change impacts $[46,80,81]$.

Delving deeper into the research findings, it is clear that the most common extreme weather events, which inflict the largest crop losses, were untimely rains $(57 \%)$, droughts $(45 \%)$ and windstorms $(6 \%)$. This conforms to the studies undertaken in many countries of the world $[80,82,83]$. Furthermore, 30\% and 35\% of respondents reported windstorms as 'common' and 'somewhat common', indicating that this form of extreme weather is also an issue that clearly affect farmers in the region. Experiences from other countries also show that extreme weather events, including strong cyclonic disturbances, have become a more common occurrence in recent years, a shift previously attributed to the impacts of climate change [84,85]. Furthermore, there were also reports of heatwaves and 
general warming of the earth $[86,87]$. The incidences of heatwaves and warmer winters were rated as the 'most common' by only 1-3\% of the respondents, demonstrating that such weather disturbances were also being felt by some Bhutanese farmers. Across the different agro-ecological locations, the extreme weather events were found to be significantly different both in terms of their frequency and severity. This shows that there is large variability in the intensity of extreme weather events that affect socio-ecological set up [88,89]. Sarpang and Samtse districts were the most impacted, with mean scores of 22.42 and 22.40, respectively, whereas Paro (16.40) had the lowest score, indicating that the former two districts were under more severe threat in comparison to the latter (Table 5). All other districts in the central and northern part of the country had scores ranging between 18.62 and 19.97, which indicates varying levels of extreme weather events throughout the surveyed region. Such a variation could be due to the geographical setting of the country, with a rapid rise and fall in altitude evident throughout Bhutan. Houze [90], who studied the orographic effects of clouds, revealed that the geophysical terrain of a place causes build-up of moisture gradients and airflow, which trigger occurrences of differing weather events. Therefore, increased incidences of extreme weather events, as well as biophysical context of the country pose a great challenge to improving food security situation of the country [38,91]. With a projected increase in the frequency and severity of extreme weather events under the impacts of climate change [4], agriculture is likely to face greater challenge under future climate scenarios [92]. It has been reported that crop damages due to the impacts of increased frequency and severity of extreme weather events are likely to increase throughout the 21st century [93]. In this context, farmers' estimate of crop loss (1-19\%) should be a matter of great concern. Though the coefficient of correlation values of crop damage to that of frequency and severity of extreme weather events were quite weak ( $r=0.2$ and 0.14 ), a positive relation between them was evident, confirming that that climate issues are one of the factors that has the potential to affect food security of the Bhutanese people. It is likely that there will be a linear increase in crop damage under increasing frequency and severity of extreme weather events as exhibited in Figure 6a,b. Pieces of evidence gathered from research outside Bhutan showed that the extreme weather events were responsible for the reduction in global food production through direct crop damage [94,95]. Therefore, there is a need to embrace climate-smart farming approaches to overcome the vulnerabilities of poor farmers in the developing countries [96,97]. There are policy-related initiatives on climate change adaptation in Bhutan. One such initiative was to identify priority activities to respond to the urgent and immediate needs with regard to the adaptation to climate change by way of framing the National Adaptation Program of Action (NAPA), which is a tool under the United Nations Framework Convention on Climate Change (UNFCCC). The NAPA projects pertain to landslide management, flood prevention and control, community-based forest fire management, disaster relief, mitigation of the effects of glacial lake outburst floods, and weather forecasting system [91]. Furthermore, the Ministry of Agriculture and Forests in Bhutan prepared the Sectoral Adaptation Plan of Action (SAPA) that included climate change adaption programmes for agriculture [98]. However, the adaptation policy has not been adequately streamlined to the development plans (five year plans), nor is there a clear research and development agenda to mitigate and adapt farming from the vagaries for climate change. The land holdings are fragmented and small and the nature of farming is basically subsistence or semi-subsistence. Hence, the reaction from the food market or mass media to the climate change effect is minimal. Therefore, there is an urgent need to come up with implementable policy instruments not only to mitigate but also overcome the issues arising due to climate change for enhanced farm resilience and improved food productivity in Bhutan.

\section{Conclusions}

The experiences of farmers on the issues and consequences of climate change impacts, including some accounts of extreme weather events, provide valuable information on the gravity of problems prevailing in rural farming communities of Bhutan. Of the many issues affecting the decisions of surveyed farmers, farm labour, irrigation, crop seasonality and climatic issues were featured as the four most prominent factors. The most common extreme weather events observed were the untimely 
rain (57\% of the respondents) and the occurrences of drought $(45 \%)$ and the rarest weather extremes were heat waves (1\% of the respondents) and heavy rain (1\%) in the study site. The most important consequence of climate change impacts was the drying of irrigation sources. These findings link well with the meteorological data, which showed decreasing rainfall and a slight increase in temperature over the last 20 years (1996-2017). Data over a longer period, to derive trends, would have been more suitable; however, such data is not available for Bhutan. Crop losses to weather events (with mean score of 4.35 and 4.10), land fallowing (2.75), the occurrence of flood and soil erosion (2.53), weed pressure (3.03) and changes in cropping pattern (3.03) were the other consequences of climate change impacts experienced by the farmers. In terms of total climate change impacts, Sarpang was the most affected, followed by Punakha, whilst Paro experienced less impact. Generally, the consequences of extreme weather events have all been experienced by the farmers surveyed at differing scales. Therefore, all these would need further research towards identifying suitable mitigation and adaptation measures through increased resource allocations for farm sustainability. Crop damage of 1-19\% due to the combined effects of extreme weather events (untimely rains, drought and windstorms) demonstrate the urgency of charting out the most appropriate action plans for improving the resilience of Bhutanese farms. Even though there are policy initiatives for the mitigation and adaptation of climate change, the mainstreaming of implementable policy instruments into the development plans needs major attention. Thus, context-based efforts, in addition to being tailored, must be backed by robust policy intervention towards a resilient agro-ecological environment and livelihood programme.

Author Contributions: Conceptualization: N.C., L.K., Y.B.; methodology: N.C., L.K., Y.B.; formal analysis: N.C.; investigation: N.C.; writing—original draft preparation: N.C.; writing—review and editing: Y.B., L.K.; supervision: L.K., Y.B. All authors have read and agreed to the published version of the manuscript.

Funding: This research received no external funding.

Acknowledgments: This paper has been prepared as part of the PhD study of Ngawang Chhogyel under the International Postgraduate Research Award (IPRA) of the University of New England (UNE), Armidale (NSW), Australia. The authors thank UNE for the scholarship and the Department of Agriculture, MoAF, Royal Government of Bhutan for granting him study leave, without which this work would not have been possible. Additionally, the authors extend gratitude to the Agriculture Extension Officers under the Department of Agriculture in Bhutan who were involved in the data collection phase of this study. Gratitude is also extended to Paul McDonald, Associate Professor at UNE for English editing (native speaking) and An Thi Noc Deng, a postgraduate student of UNE for her support during data visualization works.

Conflicts of Interest: The authors declare no conflict of interest.

\section{References}

1. Bowman, M.S.; Zilberman, D. Economic Factors Affecting Diversified Farming Systems. Ecol. Soc. $2013,18$. [CrossRef]

2. Hatfield, J.L.; Boote, K.J.; Kimball, B.A.; Ziska, L.H.; Izaurralde, R.C.; Ort, D.; Thomson, A.M.; Wolfe, D. Climate Impacts on Agriculture: Implications for Crop Production. Agron. J. 2011, 103, 351. [CrossRef]

3. Ray, D.K.; Gerber, J.S.; MacDonald, G.K.; West, P.C. Climate variation explains a third of global crop yield variability. Nat. Commun. 2015, 6, 5989. [CrossRef] [PubMed]

4. Goodess, C.M. How is the frequency, location and severity of extreme events likely to change up to 2060 ? Environ. Sci. Policy 2013, 27, S4-S14. [CrossRef]

5. Steffen, W.; Hughes, L.; Alexander, D.; Rice, M. Cranking Up the Intensity: Climate Change and Extreme Weather Events; Climate Council of Australia Ltd.: Potts Point, Australia, 2017; p. 100.

6. Troy, T.J.; Kipgen, C.; Pal, I. The impact of climate extremes and irrigation on US crop yields. Environ. Res. Lett. 2015, 10, 054013. [CrossRef]

7. Bhatta, G.D.; Aggarwal, P.K. Coping with weather adversity and adaptation to climatic variability: A cross-country study of smallholder farmers in South Asia. Clim. Dev. 2015, 8, 145-157. [CrossRef]

8. Mendelsohn, R. The Impact of Climate Change on Agriculture in Developing Countries. J. Nat. Resour. Policy Res. 2008, 1, 5-19. [CrossRef]

9. Hay, J.; Mimura, N. The changing nature of extreme weather and climate events: Risks to sustainable development. Geomat. Nat. Hazards Risk 2010, 1, 3-18. [CrossRef] 
10. IPCC. Managing Risks of Extreme Events and Disasters to Advance Climate Change Adaptation. A Special Report of Working Group I and II of the Intergovernmental Panel on Climate Change (IPCC); Field, C.B., Barros, V., Stocker, T.F., Dahe, Q., Dokken, D.J., Ebi, K.L., Mastrandrea, M., Mach, K.J., Plattner, G.-K., Allen, S.k., et al., Eds.; Cambridge University Press: Cambridge, UK; New York, NY, USA, 2012; p. 582.

11. IPCC. Summary for Policy Makers. In Climate Change 2014: Impacts, Adaptation, and Vulnerability. Part A: Global and Sectoral Aspects. Contribution to Working Group II to the Fifth Assessment Report of the Intergovernmental Panel on Climate Change; Field, C.B., Ebi, K.L., Estrada, Y.O., Barros, V.R., Dokken, D.J., Mach, K.L., Mastrandrea, M.D., Bilir, T.E., Chatterjee, M., Ebi, K.L., et al., Eds.; Cambridge University Press: Cambridge, UK; New York, NY, USA, 2014; p. 32.

12. Ummenhofer, C.C.; Meehl, G.A. Extreme weather and climate events with ecological relevance: A review. Philos. Trans. R. Soc. Lond. B Biol. Sci. 2017, 372. [CrossRef]

13. Trenberth, K.E.; Fasullo, J.T.; Shepherd, T.G. Attribution of climate extreme events. Nat. Clim. Chang. 2015, 5, 725-730. [CrossRef]

14. Wester, P.; Mishra, A.; Mukherji, A.; Shrestha, A.B. The Hindu Kush Himalaya Assessment-Mountains, Climate Change, Sustainability and People; Wester, P., Mishra, A., Mukherji, A., Shrestha, A.B., Eds.; Spinger Nature Switzerland: Basel, Switzerland, 2019; p. 638.

15. Shrestha, M.; Goodrich, C.; Udas, P.; Rai, M.; Khadgi, V. Flood Early Warning Systems in Bhutan: A Gendered Perspective. ICIMOD Working Paper 2016/13; International Centre for Integrated Mountain Development (ICIMOD): Kathmandnu, Nepal, 2016; p. 180.

16. NEC. Bhutan National Adaptation Programme of Action; National Environment Commission (NEC), Royal Government of Bhutan: Thimphu, Bhutan, 2006; p. 95.

17. Sharma, E.; Chettri, N.; Tse-ring, K.; Shrestha, A.B.; Jing, F.; Mool, P.; Eriksson, M. Climate Change Impacts and Vulnerability in the Eastern Himalayas; International Centre for Integrated Mountain Development (ICIMOD): Kathmandu, Nepal, 2009; p. 27.

18. ICIMOD. Climate Change Vulnerability of Mountain Ecosystem in the Eastern Himalayas: Climate Change Impact and Vulnerability in the Eastern Himalayas-Synthesis Report; Tse-ring, K., Sharma, E., Chettri, N., Shrestha, A., Eds.; International Centre for Integrated Mountain Development (ICIMOD): Kathmandu, Nepal, 2010; p. 110.

19. Chhogyel, N.; Kumar, L. Climate change and potential impacts on agriculture in Bhutan: A discussion of pertinent issues. Agric. Food Secur. 2018, 7, 7-79. [CrossRef]

20. Lotay, Y. Country Report Bhutan Disaster Management; Department of Disaster Management (DDM) under the Ministry of Home and Cultural Affairs (MoHCA), Royal Government of Bhutan: Thimphu, Bhutan, 2015.

21. Dorji, T.; Tamang, T. Analysis of Historical Climate and Climate Projection for Bhutan; Srinivasan, G., Raghavan, S.V., Dorji, S., Eds.; National Centre for Hydrology and Meteorology, Royal Government of Bhutan: Thimphu, Bhutan, 2019.

22. Ren, Y.Y.; Ren, G.Y.; Sun, X.B.; Shrestha, A.B.; You, Q.L.; Zhan, Y.J.; Wen, K.M.; Rajbhandari, R.; Zhang, P.F. Observed changes in surface air temperature and precipitation in the Hindu Kush Himalayan region over the last 100-plus years. Adv. Clim. Chang. Res. 2017, 8, 148-156. [CrossRef]

23. Komori, J.; Koike, T.; Yamanokuchi, T.; Tshering, P. Glacial lake outburst events in the Bhutan Himalayas. Glob. Environ. Res. 2012, 16, 59-70.

24. CDP. Vulnerability Profile of Bhutan; United Nations Committee for Development Policy (CDP): New York, NY, USA, 2018; p. 26.

25. Mool, P.K.; Wangda, D.; Bajracharya, D.; Kunzang, K.; Gurung, D.R.; Joshi, S.P. Inventry of Glaciers, Glacial Lakes, and Glacial lake Outburst Floods: Monitoring and Early Warming Systems in the Hindu Kush-Himalayan Region-Bhutan (2001); International Centre for Integrated Mountain Development (ICIMOD): Kathmandu, Nepal, 2001.

26. Bajracharya, S.R.; Maharjan, S.B.; Shrestha, F. The status and decadal change of glaciers in Bhutan from the 1980s to 2010 based on satellite data. Ann. Glaciol. 2017, 55, 159-166. [CrossRef]

27. MoAF. National Action Program to Combat Land Degradation; Ministry of Agriculture and Forests (MoAF), Royal Government of Bhutan: Thimphu, Bhutan, 2009; p. 134.

28. Sheikh, M.M.; Manzoor, N.; Ashraf, J.; Adnan, M.; Collins, D.; Hameed, S.; Manton, M.J.; Ahmed, A.U.; Baidya, S.K.; Borgaonkar, H.P.; et al. Trends in extreme daily rainfall and temperature indices over South Asia. Int. J. Climatol. 2015, 35, 1625-1637. [CrossRef] 
29. Chhogyel, N.; Kumar, L.; Bajgai, Y.; Hasan, M.K. Farmers' perception on climate change and its impacts on agriculture in different agro-ecological zones of Bhutan Himalayas. Int. J. Environ. Sci. Technol. 2020, 17. [CrossRef]

30. Herring, S.C.; Hoerling, M.P.; Kossin, J.P.; Peterson, T.C.; Scott, P.A. Explaining extreme events of 2014 from a climate perspective. Bull. Am. Meteorol. Soc. 2015, 96, S1-S172. [CrossRef]

31. Eckstein, D.; Hutfils, M.-L.; Winges, M. Global Climate Risk Index 2019. Who Suffers Most from Extreme Weather Events? Weather-Related Loss Events in 2017 and 1998 to 2017; Baum, D., Chapman-Rose, J., Hannes, R., Kier, G., Eds.; Germanwatch e.V: Bonn, Germany, 2019; p. 36.

32. Kumar, L.; Taylor, S. Exposure of coastal built assets in the South Pacific to climate risks. Nat. Clim. Chang. 2015, 5, 992-996. [CrossRef]

33. Kumar, L.; Eliot, I.; Nunn, P.D.; Stul, T.; McLean, R. An indicative index of physical susceptibility of small islands to coastal erosion induced by climate change: An application to the Pacific islands. Geomat. Nat. Hazards Risk 2018, 9, 691-702. [CrossRef]

34. Mertz, O.; Mbow, C.; Reenberg, A.; Diouf, A. Farmers' perceptions of climate change and agricultural adaptation strategies in rural Sahel. Environ. Manag. 2009, 43, 804-816. [CrossRef]

35. Harvey, C.A.; Saborio-Rodríguez, M.; Martinez-Rodríguez, M.R.; Viguera, B.; Chain-Guadarrama, A.; Vignola, R.; Alpizar, F. Climate change impacts and adaptation among smallholder farmers in Central America. Agric. Food Secur. 2018, 7. [CrossRef]

36. Wood, S.A.; Jina, A.S.; Jain, M.; Kristjanson, P.; DeFries, R.S. Smallholder farmer cropping decisions related to climate variability across multiple regions. Glob. Environ. Chang. 2014, 25, 163-172. [CrossRef]

37. NSSC and PPD. Bhutan land Cover Assessment 2010 (LCMP-2010); National Soil Service Centre (NSSC) and Policy and Planning Division (PPD), Ministry of Agriculture and Forests, Royal Government of Bhutan: Thimphu, Bhutan, 2011; p. 35.

38. NEC. Second National Communication to the UNFCCC; Namgyel, T., Dagay, S., Tashi, T., Lhaden, S., Tshering, K., Eds.; National Environment Commission (NEC), Royal Government of Bhutan: Thimphu, Bhutan, 2011.

39. Kallio, H.; Pietila, A.M.; Johnson, M.; Kangasniemi, M. Systematic methodological review: Developing a framework for a qualitative semi-structured interview guide. J. Adv. Nurs. 2016, 72, 2954-2965. [CrossRef] [PubMed]

40. Barriball, K.L.; White, A. Collecting data using a semi-structured interview: A discussion paper. J. Adv. Nurs. 1994, 19, 328-335. [CrossRef]

41. Takemura, K.; Uchida, Y.; Yoshikawa, S. Roles of extension officers to promote social capital in Japanese agricultural communities. PLoS ONE 2014, 9, e91975. [CrossRef]

42. Roy, G.L. Research Methods in Social Sciences and Extension Education; Naya Prakash: Kolkata, India, 2000.

43. Leiserowitz, A. Climate Change Risk Perception and Policy Preferences: The Role of Affect, Imagery, and Values. Clim. Chang. 2006, 77, 45-72. [CrossRef]

44. R Core Team. A Language and Environment for Statistical Computing. Available online: http://www.rproject.org (accessed on 24 March 2018).

45. Perrin, R.; Winkelmann, D. Impediments to technical progress on small versus large farms. Am. J. Agric. Econ. 1976, 58, 888-894. [CrossRef]

46. Niles, M.T.; Lubell, M.; Brown, M. How limiting factors drive agricultural adaptation to climate change. Agric. Ecosyst. Environ. 2015, 200, 178-185. [CrossRef]

47. Panda, D.K.; AghaKouchak, A.; Ambast, S.K. Increasing heat waves and warm spells in India, observed from a multiaspect framework. J. Geophys. Res. Atmos. 2017, 122, 3837-3858. [CrossRef]

48. Pandey, R.; Bardsley, D.K. Social-ecological vulnerability to climate change in the Nepali Himalaya. Appl. Geogr. 2015, 64, 74-86. [CrossRef]

49. Poudel, S.; Funakawa, S.; Shinjo, H. Household Perceptions about the Impacts of Climate Change on Food Security in the Mountainous Region of Nepal. Sustainability 2017, 9, 641. [CrossRef]

50. Nandargi, S.; Dhar, O.N. Extreme Rainstorm Events over the Northwest Himalayas during 1875-2010. J. Hydrometeorol. 2012, 13, 1383-1388. [CrossRef] 
51. Gbetibouo, G.A. Understanding Farmers' Perceptions and Adaptations to Climate Change and Variability: The Case of the Limpopo Basin, South Africa; International Food Policy Research Institute (IFPRI): Washington, DC, USA, 2009; pp. 1-52.

52. Aimin, H. Uncertainty, Risk Aversion and Risk Management in Agriculture. Agric. Agric. Sci. Procedia 2010, 1, 152-156. [CrossRef]

53. NSB. Statistical Year Book of Bhutan 2016, 34th ed.; National Statistics Bureau (NSB), Royal Government of Bhutan: Thimphu, Bhutan, 2016; p. 325.

54. DoA. Agriculture Statistics 2016; Department of Agriculture (DoA), Ministry of Agriculture and Forests, Royal Government of Bhutan: Thimphu, Bhutan, 2016; p. 81.

55. DoA. Agriculture Statistics 2015; Department of Agriculture (DoA), Ministry of Agriculture and Forests, Royal Government of Bhutan: Thimphu, Bhutan, 2015; p. 100.

56. Chapagain, T.; Raizada, M.N. Agronomic Challenges and Opportunities for Smallholder Terrace Agriculture in Developing Countries. Front. Plant Sci. 2017, 8, 331. [CrossRef] [PubMed]

57. Prasad, D.S.; Shiba, B. Climate Change and Its Effect on Water Resources: A Case Study in Annapurna Conservation Area Project (Acap). J. Climatol. Weather Forecast. 2016, 4. [CrossRef]

58. Knight, J.; Deng, Q.; Li, S. The puzzle of migrant labour shortage and rural labour surplus in China. China Econ. Rev. 2011, 22, 585-600. [CrossRef]

59. Molden, D.J.; Vaidya, R.A.; Shrestha, A.B.; Rasul, G.; Shrestha, M.S. Water infrastructure for the Hindu Kush Himalayas. Int. J. Water Resour. Dev. 2014, 30, 60-77. [CrossRef]

60. Mukherji, A.; Molden, D.; Nepal, S.; Rasul, G.; Wagnon, P. Himalayan waters at the crossroads: Issues and challenges. Int. J. Water Resour. Dev. 2015, 31, 151-160. [CrossRef]

61. Turral, H.; Burke, J.; Faures, J.-M. Climate Change, Water and Food Security; Food and Agriculture Organization (FAO) of the United Nations: Rome, Italy, 2011; p. 200.

62. Zhang, Y.; Mu, J.; Musumba, M.; McCarl, B.; Gu, X.; Zhou, Y.; Cao, Z.; Li, Q. The Role of Climate Factors in Shaping China's Crop Mix: An Empirical Exploration. Sustainability 2018, 10, 3757. [CrossRef]

63. Bailey, R.G. Delineation of ecosystem regions. Environ. Manag. 1983, 7, 365-373. [CrossRef]

64. IPCC. Climate Change 2013. The Physical Science Basis. Contribution of Working Group I to the Fifth Assessment Report of the Intergovernmental Panel on Climate Change (IPCC); Stocker, T.F., Qin, D., Plattner, G.K., Tignor, M., Allen, S.K., Boschung, J., Nauels, A., Xia, Y., Bex, V., Midgley, P.M., Eds.; Cambridge University: Cambridge, UK; New York, NY, USA, 2013; p. 1535.

65. NSB. Population and Housing Census of Bhutan; National Statistics Bureau (NSB), Royal Government of Bhutan: Thimphu, Bhutan, 2017; p. 268.

66. Tenzin, J.; Phuntsho, L.; Lakey, L. Climate Smart Agriculture: Adaptation \& Mitigation Strategies to Climate Change in Bhutan. In Climate Smart Agriculture: Strategies to Respond to Climate Change; Shrestha, R.B., Boktiar, S., Eds.; SAARC Agriculture Centre (SAC): Dhaka, Bangladesh, 2019; pp. 37-61.

67. NSB. Statistical Year Book of Bhutan 2018, 36th ed.; National Statistics Bureau (NSB), Royal Government of Bhutan: Thimphu, Bhutan, 2018; p. 325.

68. Rankin, M.; Gálvez Nogales, E.; Santacoloma, P.; Mhlanga, N.; Rizzo, C. Public-Private Partnerships for Agricultural Transformation-Trends and Lessons from Developing Countries; Emerald Publishing Limited: Bingley, UK, 2017; pp. 191-219. [CrossRef]

69. Hermans, F.; Geerling-Eiff, F.; Potters, J.; Klerkx, L. Public-private partnerships as systemic agricultural innovation policy instruments-Assessing their contribution to innovation system function dynamics. NJAS Wagening J. Life Sci. 2019, 88, 76-95. [CrossRef]

70. Ferroni, M.; Castle, P. Public-Private Partnerships and Sustainable Agricultural Development. Sustainability 2011, 3, 1064-1073. [CrossRef]

71. Dalal, N.; Joshi, A.; Soragi, B.; Chaudhary, S.; Sharma, S.; Naidu, S.; Kazmi, Y. People's Perception to Climate Change in Remote Himalayan Mountains and Rainfall Variability in the Kailash Sacred Landscape-India. J. Climatol. Weather Forecast. 2018, 6. [CrossRef]

72. Rosenzweig, C.; Iglesias, A.; Yang, X.B.; Epstein, P.R.; Chivian, E. Climate change and extreme weather events, Implications for food production, plant diseases, and pests. Glob. Chang. Hum. Health 2001, 2, 90-104. [CrossRef] 
73. Linnenluecke, M.K.; Griffiths, A.; Winn, M. Extreme Weather Events and the Critical Importance of Anticipatory Adaptation and Organizational Resilience in Responding to Impacts. Bus. Strategy Environ. 2012, 21, 17-32. [CrossRef]

74. NEC. National Environment Protection Act; National Environment Commission (NEC), Royal Government of Bhutan: Thimphu, Bhutan, 2007; p. 48.

75. Wangdi, T.; Lhendup, P.; Wangdi, N. An Analysis of Forestry Policy, Acts and Rules of Bhutan to Mainstream Climate Change Adaptation. Regional Climate Change Adaptation Knowledge Platform for Asia, Partner Report; Stockholm Environment Institute, Bangkok: Bangkok, Thailand, 2013; p. 25.

76. WB. Bhutan Forest Note: Pathways for Sustainable Forest Management and Socio-Equitable Economic Development; The World Bank (WB): Washington, DC, USA, 2019; p. 50.

77. Thinley, P.; Lassoie, J.P. Human-Wildlife Conflicts in Bhutan: Promoting Biodiversity Conservation and Rural Livelihoods; Cornell University: Ithaca, NY, USA, 2013; p. 15.

78. NPPC and WWF. Human-Wildlife Conflict SAFE Strategy; National Plant Protection Centre (NPPC) and World Wildlife Fund (WWF) Project of Ministry of Agriculture and Forests, Royal Government of Bhutan: Thimphu, Bhutan, 2016; p. 44.

79. NLC. The Land Act of Bhutan 2007; National Land Commision (NLC), Royal Government of Bhutan: Thimphu, Bhutan, 2007; p. 96.

80. Shannon, H.D.; Motha, R.P. Managing weather and climate risks to agriculture in North America, Central America and the Caribbean. Weather Clim. Extrem. 2015, 10, 50-56. [CrossRef]

81. Thornton, P.K.; Ericksen, P.J.; Herrero, M.; Challinor, A.J. Climate variability and vulnerability to climate change: A review. Glob. Chang. Biol. 2014, 20, 3313-3328. [CrossRef]

82. De, U.S.; Rao, G.S.P. Extreme weather events over India in the last 100 years. J. Indian Geophys. Union 2005, 9, 173-187.

83. Lassa, J.A.; Lai, A.Y.-H.; Goh, T. Climate extremes: An observation and projection of its impacts on food production in ASEAN. Nat. Hazards 2015, 84, 19-33. [CrossRef]

84. Yumul, G.P.J.; Cruz, N.A.; Servando, N.T.; Dimalanta, C.B. Extreme weather events and related daisters in the Philippines, 2004-2008: A sign of what climate change will mena? Disasters 2011, 35, 362-382. [CrossRef]

85. Van Oldenborgh, G.J.; van der Wiel, K.; Sebastian, A.; Singh, R.; Arrighi, J.; Otto, F.; Haustein, K.; Li, S.; Vecchi, G.; Cullen, H. Attribution of extreme rainfall from Hurricane Harvey, August 2017. Environ. Res. Lett. 2017, 12, 124009. [CrossRef]

86. Hashim, J.H.; Hashim, Z. Climate Change, Extreme Weather Events, and Human Health Implications in the Asia Pacific Region. Asia Pac. J. Public Health 2016, 28, 8S-14S. [CrossRef] [PubMed]

87. $1 \mathrm{~m}$, E.S.; Pal, J.S.; Eltahir, E.A.B. Deadly heat waves projected in the densely populated agricultural regions of south Asia. Sci. Adv. 2017, 3, e1603322. [CrossRef]

88. Lazaro, P.M. Extreme Heat Events in San Juan Puerto Rico: Trends and Variability of Unusual Hot Weather and its Possible Effects on Ecology and Society. J. Climatol. Weather Forecast. 2015, 3. [CrossRef]

89. Hoy, A.; Katel, O.; Thapa, P.; Dendup, N.; Matschullat, J. Climatic changes and their impact on socio-economic sectors in the Bhutan Himalayas: An implementation strategy. Reg. Environ. Chang. 2015, 16, 1401-1415. [CrossRef]

90. Houze, R.A. Orographic effects on precipitating clouds. Rev. Geophys. 2012, 50. [CrossRef]

91. NEC. National Adaptation Programme of Action: Updates of Projects and Profiles 2012; National Environment Commission (NEC), Royal Government of Bhutan: Thimphu, Bhutan, 2012; p. 60.

92. Gopalakrishnan, T.; Hasan, M.K.; Haque, A.T.M.S.; Jayasinghe, S.L.; Kumar, L. Sustainability of Coastal Agriculture under Climate Change. Sustainability 2019, 11, 7200. [CrossRef]

93. Mahdi, S.S.; Dhekale, B.S.; Choudary, S.R.; Bangroo, S.A.; Gupta, S.K. On the climate risk in crop production and management in India: A review. Aust. J. Crop Sci. 2015, 9, 585-595.

94. Lesk, C.; Rowhani, P.; Ramankutty, N. Influence of extreme weather disasters on global crop production. Nature 2016, 529, 84-87. [CrossRef]

95. Zampieri, M.; Ceglar, A.; Dentener, F.; Toreti, A. Wheat yield loss attributable to heat waves, drought and water excess at the global, national and subnational scales. Environ. Res. Lett. 2017, 12, 064008. [CrossRef]

96. Lipper, L.; Thornton, P.; Campbell, B.M.; Baedeker, T.; Braimoh, A.; Bwalya, M.; Caron, P.; Cattaneo, A.; Garrity, D.; Henry, K.; et al. Climate-smart agriculture for food security. Nat. Clim. Chang. 2014, 4, 1068-1072. [CrossRef] 
97. Hasan, M.K.; Desiere, S.; D'Haese, M.; Kumar, L. Impact of climate-smart agriculture adoption on the food security of coastal farmers in Bangladesh. Food Secur. 2018, 10, 1073-1088. [CrossRef]

98. MoAF. The Renewable Natural Resources (RNR) Sector Adaptation Plan of Action, 2016; RNR Climate Change Adaptation Program; Ministry of Agriculture and Forests (MoAF), Royal Government of Bhutan: Thimphu, Bhutan, 2016; p. 44.

(C) 2020 by the authors. Licensee MDPI, Basel, Switzerland. This article is an open access article distributed under the terms and conditions of the Creative Commons Attribution (CC BY) license (http://creativecommons.org/licenses/by/4.0/). 